\title{
CORRIGENDUM
}

\section{Pheromone emission patterns and courtship sequences across distinct populations within Anastrepha fraterculus (Diptera-Tephitidae) cryptic species complex - CORRIGENDUM}

\section{A.K.P. Roriz, H.F. Japyassú, C. Cáceres, M. Teresa Vera and} I.S. Joachim-Bravo

doi:10.1017/S0007485318000846, Published by Cambridge University Press, 29 November 2018.

The authors apologise for two errors in the original version of this article. It was published with an error in the title and one incorrect author name. A notice detailing these has been published and the error rectified in both the PDF and HTML versions.

\section{Reference}

Roriz, A.K.P., Japyassú, H.F., Cáceres, C., Teresa Vera, M. \& Joachim-Bravo, I.S. Pheromone emission patterns and courtship sequences across distinct populations within Anastrepha fraterculus (Diptera-Tephitidae) cryptic species complex. B. Entomol. Res. Published by Cambridge University Press, 29 November 2018. doi:10.1017/S0007485318000846. 